\title{
"The role of institutional ownership in strengthening to the enterprise value on the banking issuers"
}

\begin{tabular}{|c|c|}
\hline \multirow{5}{*}{ AUTHORS } & Iskandar Muda (D https://orcid.org/0000-0001-6478-9934 \\
\hline & Erlina \\
\hline & Muhammad Panca Diharja \\
\hline & Normah Haji Omar (D https://orcid.org/0000-0003-3328-8832 \\
\hline & Jamaliah Said iD https://orcid.org/0000-0003-1912-2529 \\
\hline ARTICLE INFO & $\begin{array}{l}\text { Iskandar Muda, Erlina, Muhammad Panca Diharja, Normah Haji Omar and } \\
\text { Jamaliah Said (2019). The role of institutional ownership in strengthening to the } \\
\text { enterprise value on the banking issuers. Banks and Bank Systems, 14(1), 42-54. } \\
\text { doi:10.21511/bbs.14(1).2019.05 }\end{array}$ \\
\hline DOI & http://dx.doi.org/10.21511/bbs.14(1).2019.05 \\
\hline RELEASED ON & Friday, 08 February 2019 \\
\hline RECEIVED ON & Friday, 11 May 2018 \\
\hline \multirow[t]{2}{*}{ ACCEPTED ON } & Thursday, 24 January 2019 \\
\hline & $(\mathrm{cc}) \mathrm{EY}_{\mathrm{EY}}$ \\
\hline LICENSE & $\begin{array}{l}\text { This work is licensed under a Creative Commons Attribution } 4.0 \text { International } \\
\text { License }\end{array}$ \\
\hline JOURNAL & "Banks and Bank Systems" \\
\hline ISSN PRINT & 1816-7403 \\
\hline ISSN ONLINE & $1991-7074$ \\
\hline PUBLISHER & LLC “Consulting Publishing Company "Business Perspectives" \\
\hline FOUNDER & LLC "Consulting Publishing Company "Business Perspectives" \\
\hline
\end{tabular}

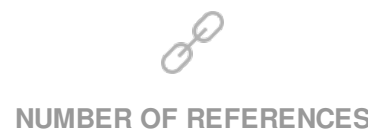

61
NUMBER OF FIGURES

5
NUMBER OF TABLES

10

(C) The author(s) 2021. This publication is an open access article. 


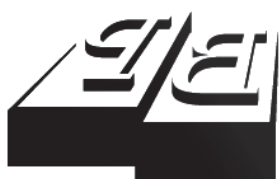

BUSINESS PERSPECTIVES

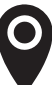

LLC "CPC "Business Perspectives" Hryhorii Skovoroda lane, 10, Sumy, 40022, Ukraine

www.businessperspectives.org

Received on: $11^{\text {th }}$ of May, 2018 Accepted on: $24^{\text {th }}$ of January, 2019

(C) Iskandar Muda, Erlina, Muhammad Panca Diharja, Normah Haji Omar, Jamaliah Said, 2019

Iskandar Muda, Associate Professor, Department of Accounting, Faculty of Economics and Business, Universitas Sumatera Utara, Medan, North Sumatera, Indonesia.

Erlina, Professor, Department of Accounting, Faculty of Economics and Business, Universitas Sumatera Utara, Medan, North Sumatera, Indonesia.

Muhammad Panca Diharja, Master of Accountancy, Faculty of Economics and Business, Universitas Sumatera Utara, Medan, North Sumatera, Indonesia.

Normah Haji Omar, Professor, Accounting Research Institute, Universiti Teknologi MARA, Malaysia.

Jamaliah Said, Professor, Accounting Research Institute, Universiti Teknologi MARA, Malaysia.

\section{(ㄷ)(ㄱ)}

This is an Open Access article, distributed under the terms of the Creative Commons Attribution 4.0 International license, which permits unrestricted re-use, distribution, and reproduction in any medium provided the original work is properly cited.
Iskandar Muda (Indonesia), Erlina (Indonesia), Muhammad Panca Diharja (Indonesia), Normah Haji Omar (Malaysia), Jamaliah Said (Malaysia)

\section{THE ROLE OF INSTITUTIONAL OWNERSHIP IN STRENGTHENING THE ENTERPRISE VALUE ON THE BANKING ISSUERS}

\begin{abstract}
This study examines the role of institutional ownership in moderating the relation between fundamental factors of a company and Corporate Social Responsibility (CSR) and Enterprise Value (firm value). The type of this research is an explanation research method. The sampling method was a proportional random sampling method of the population of banking companies of the Indonesian Stock Exchange. The method of data collection was documentation. The method of data analysis was Multiple Regression Analysis. The results of this study showed that simultaneous net profit margin and corporate social responsibility had a significant effect on the firm value. Partial test shows that net profit margin variables had an effect on the firm value and corporate social responsibility variables, which consist of economy, and had no influence on firm value. The results also indicated that institutional ownership strengthened the relation of fundamental factors and corporate social responsibility with the Enterprise Value.
\end{abstract}

\section{Keywords}

JEL Classification enterprise value (firm value), net profit margin, corporate social responsibility, institutional ownership

\section{INTRODUCTION}

The responsibility of managing the organization, which was originally for shareholders only, shifted to stakeholders (owners, employees and government). On July 5, 2007, a United Nation Global Compact international conference was held, attended by more than 600 senior executives of the world corporation. The purpose of the conference was to improve business practices with respect to the environment and social aspects inside and outside the company. Corporations were asked to show greater concern and community responsibility. The implementation of CSR in public banking companies in Malaysia has succeeded in integrating stakeholder interests as the company's goal of earning profit but still paying attention to aspects of sustainable social and environmental responsibility and company commitments that pay attention to non-financial aspects (Jaiyeoba et al., 2018; Jusoh \& Ibrahim, 2018; Jie \& Hasan, 2018; Rahman \& Ismail, 2018). Several dimensions of organizational strategy applied by Malaysian banking public companies in the successful CSR implementation are Visibility, Voluntarism, Proactivity, Specificity and Centrality. The implementation of CSR in six banking public companies in Malaysia was carried out in the aspect of management process voluntary ethical behavior and social obligation. Information on corporate social and environmental involvement as well as non-financial information is delivered to stakeholders. These activities are communicated with the annual financial report. The annual financial report is submitted at the Note 


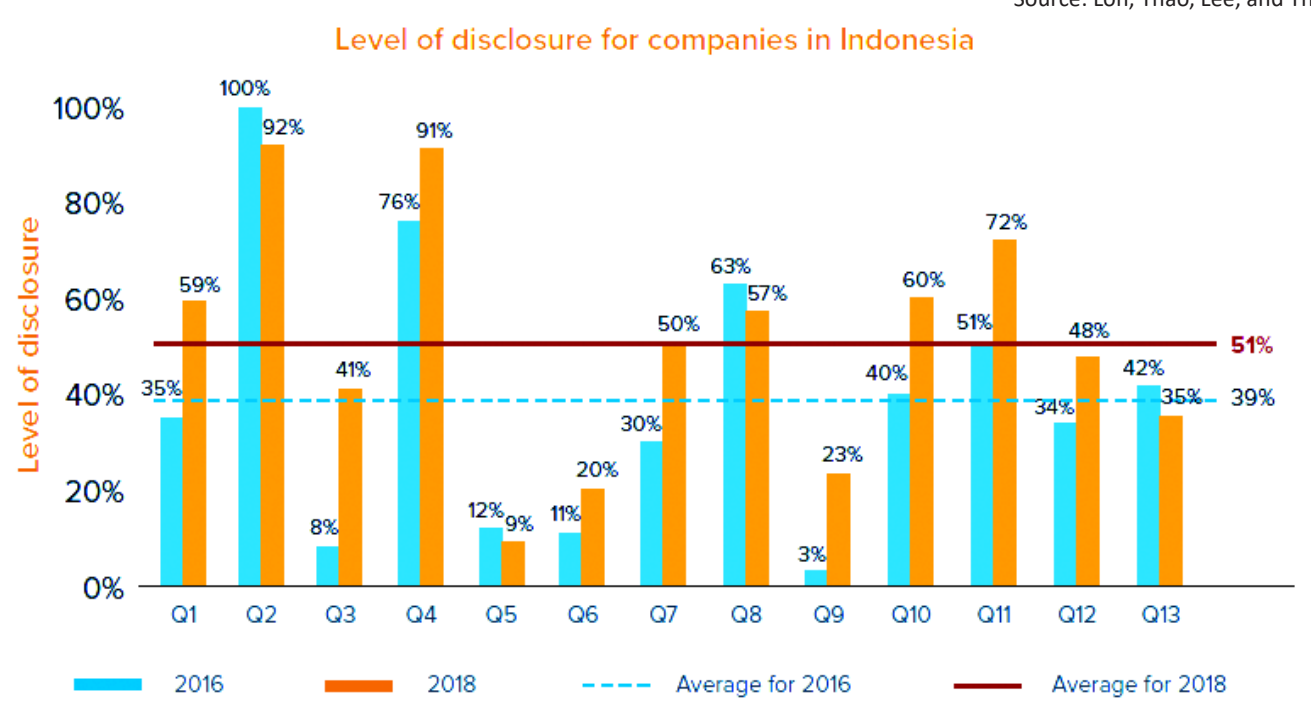

Figure 1. The levels of Indonesian companies disclosure

financial statement post. Based on research conducted by Loh et al. (2018), the following levels of a company disclosure are defined (see Figure 1).

Based on Figure 1, the level of disclosure of public companies in Indonesia is seen for 2018 with a score of $51 \%$. As a comparison, the levels of public companies disclosure in Malaysia in 2018 are presented in Figure 2.

Based on Figure 2, the level of disclosure of public companies in Malaysia is seen for 2018 with a score of 53\%. The development of CSR implementation in Indonesia is marked, many companies have implemented CSR. More and more companies are implementing CSR in both charity and empowerment. At least it can be seen from the incessant publications related to the implementation of CSR in print and electronic media. This global phenomenon also hit Indonesia. The development of CSR in Indonesia can be seen from the various efforts of Provincial, District and City Governments to issue legislation related

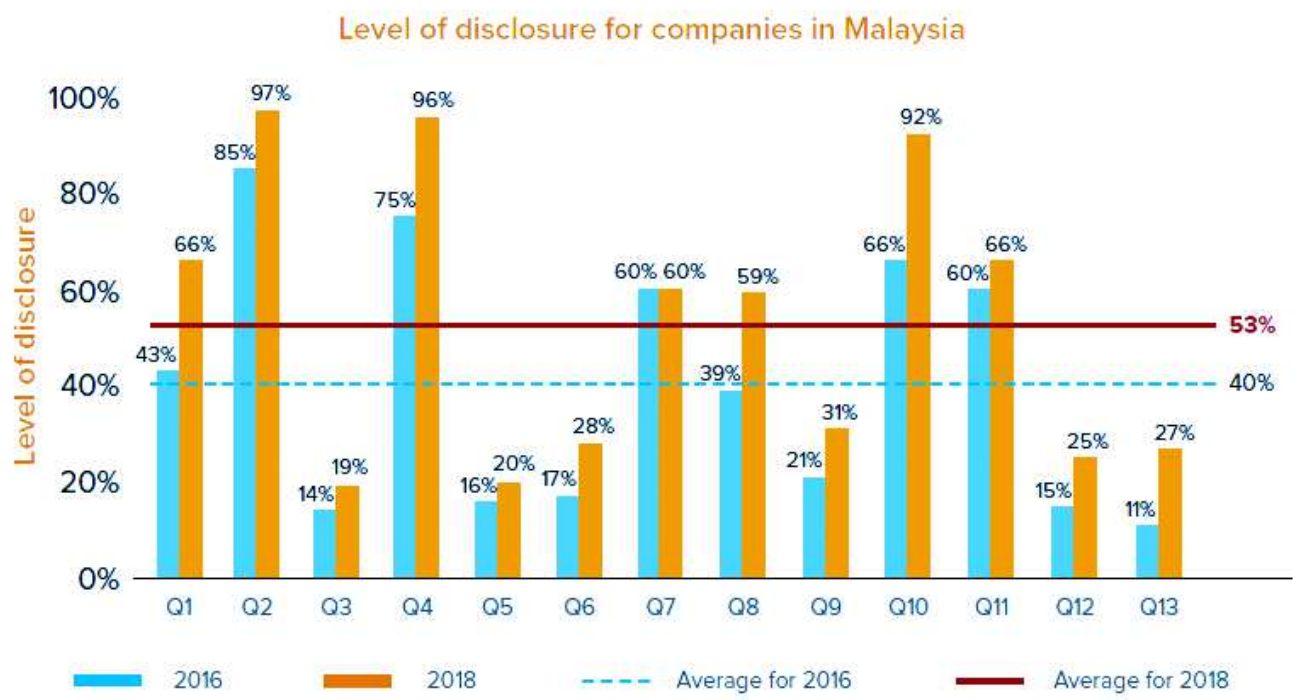

Figure 2. The levels of Malaysian companies disclosure 
to the CSR implementation in the provinces, districts and cities concerned. The goal of a company is to maximize the firm value or shareholders' wealth. Maximizing firm value is considered more appropriate as the objective of a company because maximizing firm value means maximizing current value of all future profit of the shareholders. Firm value is reflected in stable stock price, which increases in the long term. The higher the stock price, the higher the firm value (Li \& Zaiats, 2018; Bedendo \& Siming, 2018; Chen et al., 2018; Saona \& San Martin, 2018; Rao, 2018; and Chou \& Chan, 2018). Firm value can describe the condition of a company. If a company has good firm value, potential investors will view it positively and vice versa. High firm value shows good company performance. It includes creditor's view of firm value. For a creditor, firm value is related with company liquidity, meaning a company's ability to return loan given by a creditor (Ngoc, 2018; Jamali \& Karam, 2018; Salehzadehet et al., 2018; Al-Abdin et al., 2018; Idowu, 2018; Adelopo et al., 2018; and Ameer et al., 2018). If firm value is implied to be poor, an investor will give the company a low value. The value of a public company is from the price of stocks issued by the company (Laoworapng et al., 2018). CSR occurs when CSR activity has actually taken place. In this case, the social department is the initial actors of CSR activities in Indonesia. After 2007, the Law No. 40 of 2007 on Limited Liability Company has been issued, almost all Indonesian companies have conducted CSR program, although again the activity is still going on the stage of seeking popularity and attachment of government regulation. For example, there are still many companies that, when providing assistance, the recipient must stick to the company's poster in place as a sign that he has received help from the company.

There are many factors which can determine firm value. One of them is profitability, which is a financial factor. Profitability is a factor, which affects firm value (Khumairoh, 2016). Profitability is a company's ability to produce profit at a certain level of sales, assets and capital (Chen et al., 2018; Eckardt et al., 2018; Guiso \& Rustichini, 2018). One of the important indicators for an investor in assessing a company's future prospect is the growth of the company's profitability. High profitability reflects good prospect. The higher the profitability of a company, the higher the efficiency of the company, so the company performance is also good. In this study, profitability is proxied by Return on Equity, Return on Assets, Net Profit Margin as measurements of company profitability. Corporate Social Responsibilty is a form of a company's responsibility in improving social gap and environmental damage due to the operational activities of the company (Blasi et al., 2018; Schipani et al., 2018; Byun, 2018; Civera et al., 2018; Salvioni et al., 2018). The more forms of responsibility performed by a company to its environment, the better the corporate image. Investors are more interested in companies that have good image in the society because the better the corporate image, the higher the customer loyalty (De Jong et al., 2018). Increased customer loyalty will increase sales and profitability. This makes business run smoothly, so firm value will increase. The description shows that CSR can increase profitability and firm value. The company not only has economic and legal obligations to shareholders but also obligations to other interested parties that are stakeholders whose scope exceeds the obligations. The underlying idea of corporate social responsibility that is often considered the core of business ethics is that the company not only has economic and legal obligations but also obligations to stakeholders whose scope exceeds the obligation.

Institutional shareholder is a government, a financial institution, a legal entity, a foreign institution, a trust fund, and other institutions which hold corporate stock. Institutional ownership in a company encourages increased monitoring on management performance. The bigger the institutional ownership, the bigger the vote and pressure on the financial institution to monitor its management, thus giving encouraging management more to optimize company performance and align management's interest and stakeholder's interest (Titus et al., 2018). The implementation of Corporate Social Responsibility reveal is a factor which can draw shareholder's interest to invest. Investors are more interested in investing in companies which implement Corporate Social Responsibility program as their business activities. Therefore, the researcher was interested in studying the influence of profitability and corporate social responsibility on firm value with institutional ownership as a moderating variable. 


\section{LITERATURE REVIEW}

\subsection{Enterprise value}

Enterprise value was defined as market value in this study. Another name for firm value is enterprise value, which is a description of the size of the company's economic value as the price of the owner's takeover value when purchased at a certain time (Vaida, 2017). Formula (1) that can be presented is as follows:

Enterprise Value $=$ $=($ Market $C a p+$ Debt + Preferred equity +

+ Minority interest) -

-Cash and cash equivalents.

Other models modified by Chung and Pruitt (1994) include:

$$
q=(M V S+M V D) / R V A,
$$

where $M V D$ - the market value of all liabilities (debt), RVA - the replacement value of all production capacity, MVS - the market value for all outstanding stock.

From formula (2) it is concluded that the company is of high value if the $q$ value is greater than one, which means a good investment opportunity for investors and so is the value of the company generated from the formula. The $q$ value is less than one, and investment opportunities are inadequate for investors. The next formula is (Sial et al., 2018):

$$
\text { Tobin's } Q=\frac{E M V+D}{E B V+D},
$$

where $E M V$ - the equity market value plus the debt on market value, $E B V$ - the equity book value plus the debt on market value, Tobin $Q$ - the equity market value/the equity book value.

Formula (3) above shows the market value which is the price that occurs from the process of bargaining on the stock market (Sial et al., 2018). This value can only be determined if the company shares are sold on the stock market. Firm value is an important indicator for investor to assess company comprehensively (Li \& Zaiats, 2018). Firm value is very important because high corporate value will be followed by high shareholder wealth. High firm value is the desire of the owners of the company, because high value shows that the shareholder prosperity is also high. Market price of the stock reflects the wealth of shareholders and expediency of investment decisions and management. The value of the ownership stock can be an appropriate index to measure the level of corporate effectiveness. For this reason, the financial management objectives are expressed in the form of maximizing the value of shares of the company ownership, or maximizing stock prices. The goal of maximizing stock prices does not mean that managers should seek to increase stock value at the expense of shareholders.

\subsection{Net profit margin}

Net Profit Margin (NPM) describes net profit received by a company by very sales. In other words, this ratio measures net profit after tax on sales. The higher NPM value indicates that the company is more efficient. Companies can suppress unnecessary costs, so the company is able to maximize the net profit earned. The company will develop faster into a company with great equity. However, the percentage of net income that goes into equity is much higher than the percentage of net income distributed as dividends (Saona \& Martin, 2018). NPM is used to determine which companies with certain revenue succeed in producing maximum net income. Such companies are more efficient in operations than other companies. However, it should be noted that comparing the NPM ratio of a company to another company should be done in the same sector. Taking this, the NPM between sectors is clearly very different. Figure 3 illustrates the ability of companies to generate profits from several scenarios if there is an increase in expenses and cost, the more ineffective existing financial model and the lower value of the company. Likewise, the increasing leverage scale shows the ineffectiveness. This is illustrated in Figure 3.

Based on Figure 3, the low NPM shows an ineffective cost structure and a poor pricing strategy and will have an impact on increasing company leverage. This is due to management inefficiencies. Investors need NPM information as a measure of organizational profitability. 


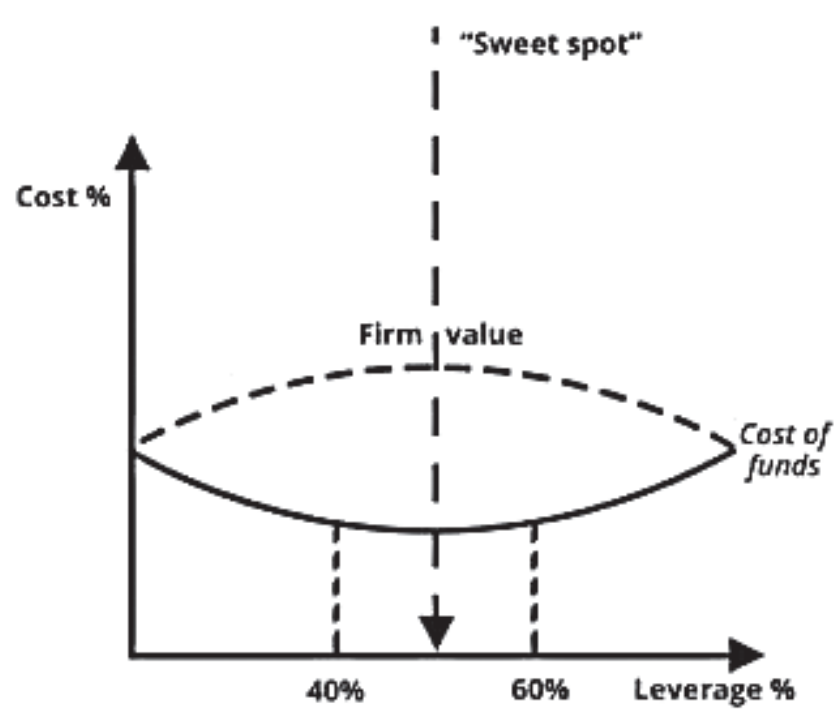

Figure 3. Several scenarios of an increase in the enterprise value with the NPM

\subsection{Corporate social responsibility}

Social and environmental responsibility is a company's commitment to contribute in developing sustainable economy to improve quality of life and beneficial environment, whether for the company, local community, or society in general (Tran, 2018; Baldini et al., 2018; Knudsen, 2018; Bhardwai et al., 2018; Paynter, 2018; Loosemore \& Lim, 2018; Spanos, 2018; Maqbool \& Zameer, 2018; Buranatrakul \& Swierczek, 2018; ElGammal et al., 2018). Corporate Social Responsibility is a phenomenon and a strategy used by companies to accommodate the needs and interests of their stakeholders. CSR begins in an era where the awareness of long-term corporate sustainability is more important than just the profitability of a company. If CSR is truly implemented effectively then it can strengthen or increase the accumulation of social capital in order to improve the community welfare. Economic growth can be affected by networking, trust, mutual and social collaboration. Through a variety of mechanisms, social capital can increase the level of responsibility for the public interest, the widespread participation in the democratic process, the strengthening of community harmony and the decline in violence.

Corporate responsibility towards the public interest can be realized through the implementation of sustainable CSR programs and direct touch to the aspects of community life. Thus, the realization of CSR programs is a corporate contribution indirectly to the strengthening of social capital as a whole. Unlike the case with financial capital that can be calculated as quantitative value, then social capital cannot be calculated with certainty. However, it can be asserted that the expenditure of CSR programs is a firm investment in fostering social capital.

\subsection{Institutional ownership}

Institutional shareholder is a government, a financial institution, a legal entity, a foreign institution, a trust fund, and other institutions holding corporate stock. Institutional ownership is one of the factors that can affect the company performance (Faller \& Zu, 2018; Lamb \& Butler, 2018; Mota \& Uchida, 2018). The existence of ownership by institutional investors will encourage more optimal supervision of management performance, since share ownership represents a source of power that can be used to support or otherwise the management performance (Buchanan et al., 2018; Hu et al., 2018; and Paynter et al., 2018). Institutional ownership is one of the factors that can affect the performance of the company. Optimal supervision of the performance of managers will make the decision-making procedure more careful. The conceptual framework can be described in Figure 4. 


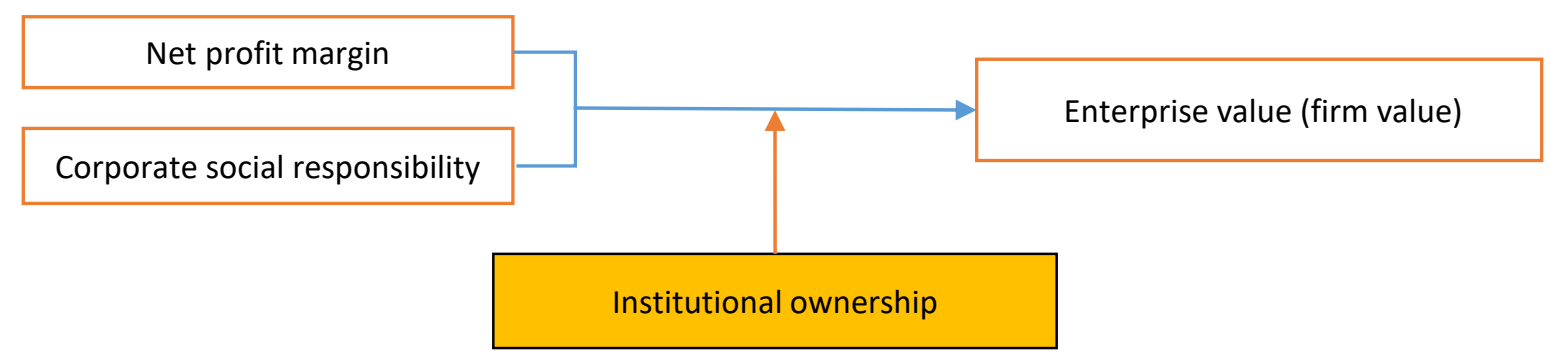

Figure 4. Conceptual framework

Based on Figure 4, if managerial ownership is high, it can have a negative impact on the company because it can create defense problems. This means that with high managerial ownership, they have a strong position to exercise control over the company and external stakeholders will have difficulty controlling the actions of managers (Cordeiro et al., 2018). This is due to the high voting rights owned by managers.

\section{METHODS}

The population of this study was 33 banking companies listed on the Indonesia Stock Exchange. The sampling technique for this study was Slovin's formula by proportional random sampling. The sample in this study was made by 29 banking companies with 10-year (2007-2016) observation period, so that total research data was 29 banking companies $\times 10$ years $=290$ observation data. The operationalization of this research variable is presented in Table 1.

As Table 1 shows, for the operationalization of variables, two dependent variables are used, one moderating variable and one dependent variable. Descriptive statistics was used to provide a summary of research data which consisted of: mean, maximum, minimum, and standard deviation. The basis of decision making in KolmogorovSmirnov's test could be probability value (significance), which is 1 if probability value $>0.05$, then data distribution is normal or equals 2 if probability value 0.05 , then data distribution is abnormal. Multicollinearity test aims to examine whether regression model contains any correlation between independent variables. A regression model has multicollinearity if there is perfect linear relation between several or all independent variables of the regression model. Multicollinearity test can be viewed from tolerance and Variance Inflating Factor (VIF) values. Autocorrelation is correlation between members of a series of observation in a time series or in a spatial series (in cross sectional data). One of the tests of autocorrelation is Durbin-Watson's test. If $\mathrm{Du}<\mathrm{DW}<(4-\mathrm{Du})$, there is no autocorrelation. Heteroscedasticity test aims to examine whether a regression model has variance dissimilarity from the residual of one observation to another. If the variance of the residual

Table 1. Operational definition and variable measurement

\begin{tabular}{|c|c|c|c|}
\hline Variable & Operational definition & Measurement & Scale \\
\hline Net profit margin & $\begin{array}{l}\text { The ratio used to demonstrate a company's ability to generate } \\
\text { net profits }\end{array}$ & $\frac{\text { Net Income }}{\text { Sales }} \cdot 100 \%$ & Ratio \\
\hline $\begin{array}{l}\text { Corporate social } \\
\text { responsibility }\end{array}$ & $\begin{array}{l}\text { Participation of the company in sustainable economic } \\
\text { development has advantages both for the company itself and } \\
\text { society in general. Economic aspects are indicators set to } \\
\text { determine the extent of disclosure in the economic aspects to } \\
\text { be disclosed in the company's annual reporting }\end{array}$ & $C S R I_{j}=\frac{\sum X_{i j}}{n j}$ & \\
\hline $\begin{array}{l}\text { Enterprise value } \\
\text { (firm value) }\end{array}$ & $\begin{array}{l}\text { The value of the company as a market value is the price that } \\
\text { occurs from the bargaining process in the stock market. This } \\
\text { value can only be determined if the company's shares are sold } \\
\text { on the stock market }\end{array}$ & Tobin's $Q=\frac{E M V+D}{E B V+D}$ & Ratio \\
\hline $\begin{array}{l}\text { Institutional } \\
\text { ownership }\end{array}$ & $\begin{array}{l}\text { Institutional ownership is the percentage of shares owned by } \\
\text { the institution of all outstanding shares of the company. }\end{array}$ & $\begin{array}{l}\text { Number of shares owned by } \\
\text { institutional/ total shares } x \\
100 \%\end{array}$ & Ratio \\
\hline
\end{tabular}


of one observation to another is fixed, it's called homoscedasticity, and if different then it's called heteroscedasticity. Good regression model is homoscedasticity or no heteroscedasticity. To see the influences of net profit margin and corporate social responsibility on firm value, the following model was used:

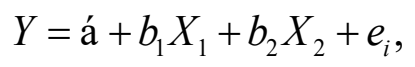

where $Y$ - firm value, $X_{1}$ - net profit margin, $X_{2}$ - corporate social responsibility, $\alpha$ - constant, $b_{1}-b_{2}-$ regression coefficient, $e_{i}-$ estimated error.

Below (4) and (5) are regression equations to see the influences of net profit margin and corporate social responsibility on firm value with institutional ownership as a moderating variable:

$$
\begin{aligned}
& Z_{1}=\mathrm{a}+b_{1} X_{1}+b_{2} X_{2}+e_{i}, \\
& |e|=a+b_{3} Y,
\end{aligned}
$$

where $Z_{1}$ - institutional ownership, $X_{1}$ - net profit margin, $X_{2}$ - corporate social responsibility, $a$ - constant, $b_{1}-b_{2}$ - regression coefficient of Independent Variable, $b_{3}$ - regression coefficient of a moderating variable, $e_{i}$ - estimated error, $|e|-$ absolute residual, $Y$ - profit management.

\section{RESULTS AND DISCUSSION}

\subsection{Results}

\subsubsection{Descriptive statistics}

Based on Table 2, the descriptive statistics was used to provide a summary of research data which consisted of mean, maximum, minimum, and standard deviation.

\section{Table 2. Descriptive statistics}

Based on Table 2, it can be concluded that the level of CSR disclosure among banking issuers is still minimal. This shows that in the future, capital market authorities can issue rules on the importance of mandatory disclosures, especially for banking issuers. The results of the normality test for residual values are presented in Figure 2. According to Syahyunan et al. (2017), the basis of decision making in Kolmogorov-Smirnov's test could be probability value (significance), which is:

- if probability value $>0.05$, then data distribution is normal;

- if probability value $\leq 0.05$, then data distribution is abnormal.

The results of normality testing data are in the Table 3.

Table 3. Normality test

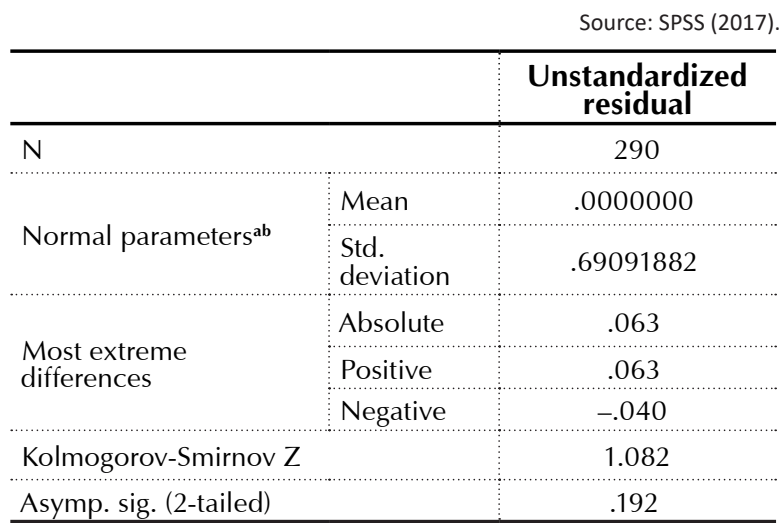

Note: $\mathrm{a}$ - test distribution is normal, $\mathrm{b}$ - calculated from data.

Based on Table 3, significance value of 0.192 is bigger than 0.05 . Thus, it's concluded that the data was normally distributed. Testing residual normality in graphic analysis by examining normal probability plot can also be performed. The results of the multicollinearity test are presented

\begin{tabular}{|c|c|c|c|c|c|}
\hline & $\mathbf{N}$ & Minimum & Maximum & Mean & Std. deviation \\
\hline NP & 290 & -1.5371 & 2.3101 & .095975 & .7105394 \\
\hline NPM & 290 & -6.9078 & 4.7118 & -.292855 & 2.5583201 \\
\hline CSR & 290 & -2.1982 & .0000 & -.534787 & .6335005 \\
\hline $\mathrm{IO}$ & 290 & -2.3026 & 4.6052 & 4.524065 & .4743695 \\
\hline Valid N (listwise) & 290 & & & & \\
\hline
\end{tabular}
in Table 4.

Source: SPSS (2017). 
Table 4. Multicollinearity test

Source: SPSS (2017)

\begin{tabular}{|c|c|c|c|c|c|c|c|}
\hline \multirow{2}{*}{ Model } & \multicolumn{2}{|c|}{ Unstandardized coefficients } & \multirow{2}{*}{$\begin{array}{c}\begin{array}{c}\text { Standardized } \\
\text { coefficients }\end{array} \\
\text { Beta }\end{array}$} & \multirow{2}{*}{$\mathbf{t}$} & \multirow{2}{*}{ Sig. } & \multicolumn{2}{|c|}{ Collinearity statistics } \\
\hline & $\mathbf{B}$ & Std. error & & & & Tolerance & VIF \\
\hline Constant & .047 & .053 & & .879 & .380 & & \\
\hline NPM & -.062 & .016 & -.225 & -3.946 & .000 & .997 & 1.003 \\
\hline CSR & -.058 & .064 & -.052 & -.912 & .363 & .997 & 1.003 \\
\hline
\end{tabular}

Note: a - dependent variable: NP.

Table 4 shows that all independent variables, i.e. net profit margin and corporate social responsibility, have tolerance value bigger than 0.1 and VIF value smaller than 10 . Therefore, regression model had no multicollinearity problem. The results of testing the symptoms of the variance of residual inequality for all observations in the linear regression model are shown in Figure 5.

Figure 5 shows that the scatterplot presents that the dots spread randomly above and under the number 0 on $Y$ axis. It's concluded that there was no heteroscedasticity in the regression model, so the regression model was feasible. Testing the correlation of variables in the prediction model with changes in time is presented in Table 5.
Table 5. Autocorrelation test

Source: SPSS (2017)

\begin{tabular}{c|c|c|c|c|c}
\hline Model & $\mathbf{R}$ & $\begin{array}{c}\mathbf{R} \\
\text { square }\end{array}$ & $\begin{array}{c}\text { Adjusted R } \\
\text { square }\end{array}$ & $\begin{array}{c}\text { Std. error of } \\
\text { the estimate }\end{array}$ & $\begin{array}{c}\text { Durbin- } \\
\text { Watson }\end{array}$ \\
\hline 1 & $233 \mathrm{a}$ & .054 & .048 & .6932809 & 1.962 \\
\hline
\end{tabular}

Note: a - predictors: (Constant), CSR, NPM; b - dependent variable: NP.

Table 5 shows that the Durbin Watson (DW) value is 1.962 . The value will be compared with the table value using significance value of $5 \%$, total sample $200(n)$ and total independent variables $2(k=2)$ so $\mathrm{du}=1.862$ so that $1.862<1.962<2.138(4-\mathrm{du})$ and it's concluded that there was no autocorrelation. Hypothesis test is a difference test between sample value and population of the value of the

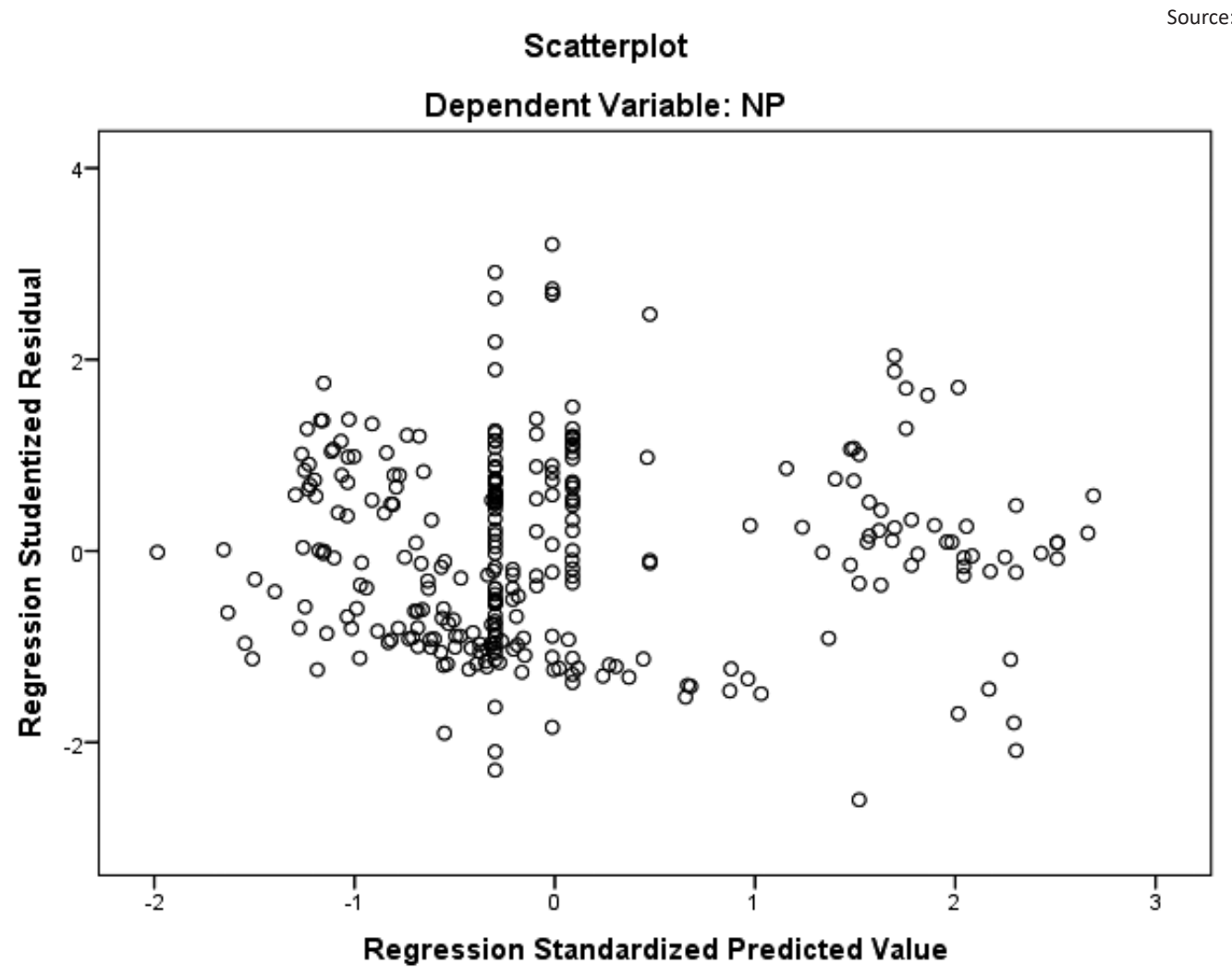

Figure 5. Heteroscedasticity test 
studied data and the expected value. The hypothesis tests were coefficient determination $\left(R^{2}\right), \mathrm{F}$ test, $\mathrm{t}$ test and residual test (moderating) (see Table 6).

Table 6. Results of the coefficient determination test

Source: SPSS (2017)

\begin{tabular}{c|c|c|c|c}
\hline Model & $\mathbf{R}$ & $\begin{array}{c}\mathbf{R} \\
\text { square }\end{array}$ & $\begin{array}{c}\text { Adjusted } \\
\mathbf{R} \text { square }\end{array}$ & $\begin{array}{c}\text { Std. error of } \\
\text { the estimate }\end{array}$ \\
\hline 1 & .233 & .054 & .048 & .6932809 \\
\hline
\end{tabular}

Note: a - predictors: (Constant), CSR_E, NPM; b - dependent variable: NP.

Table 6 shows, Adjusted R Square value is 0.049 or (4.8\%). It means that $4.8 \%$ of Firm Value could be explained by Net Profit Margin and Corporate Social Responsibility, while the remaining $95.2 \%$ was explained by other variables not included in this study. Simultaneous testing is presented in Table 7.

Table 7. F-test

Source: SPSS (2017).

\begin{tabular}{l|c|c|c|c|c}
\hline Model & $\begin{array}{c}\text { Sum of } \\
\text { squares }\end{array}$ & df & $\begin{array}{c}\text { Mean } \\
\text { square }\end{array}$ & $\mathbf{F}$ & Sig. \\
\hline Regression & 8.084 & 2 & 4.042 & 8.410 & $.000^{\mathbf{b}}$ \\
\hline Residual & 140.346 & 292 & .481 & & \\
\hline Total & 148.431 & 294 & & & \\
\hline
\end{tabular}

Note: $\mathrm{a}$ - dependent variable: NP; $\mathrm{b}$ - predictors: (Constant), CSR, NPM.

Based on Table 7 above, $\mathrm{F}$ count is 8.410 , bigger than $\mathrm{F}$ table of 3.026 , and the significance value of F test is 0.000 , smaller than alpha 0.05 . It's concluded that simultaneously, net profit margin and corporate social responsibility had significance for firm value. Partial testing is presented in Table 8.

Table 8. T-test

\begin{tabular}{|c|c|c|c|c|c|}
\hline \multirow{2}{*}{ Model } & \multicolumn{2}{|c|}{$\begin{array}{c}\text { Unstandardized } \\
\text { coefficients }\end{array}$} & \multirow{2}{*}{$\begin{array}{c}\text { Standardized } \\
\text { coefficients } \\
\text { Beta }\end{array}$} & \multirow{2}{*}{$t$} & \multirow{2}{*}{ Sig. } \\
\hline & B & $\begin{array}{l}\text { Std. } \\
\text { error }\end{array}$ & & & \\
\hline (Constant) & .047 & .053 & & .879 & .380 \\
\hline NPM & -.062 & .016 & -.225 & -3.946 & .000 \\
\hline CSR & -.058 & .064 & -.052 & -.912 & .363 \\
\hline
\end{tabular}

Based on the results of Table 8, partially the influence of each independent variable on the dependent variable is described as follows:

1. Variable net profit margin with significance value of 0.000 is smaller than alpha 0.05 . It meant variable net profit margin partially influenced firm value.

2. Variable corporate social responsibility with significance value of 0.363 is higher than alpha 0.05 . It meant variable corporate social responsibility did not influence firm value.

The testing of the moderation impact used by the Residual Test is found in Table 9.

Table 9. Results of the first residual test

Source: SPSS (2017)

\begin{tabular}{l|c:c:c:c|c}
\hline \multirow{2}{*}{ Model } & $\begin{array}{c}\text { Unstandardized } \\
\text { coefficients }\end{array}$ & $\begin{array}{c}\text { Standardized } \\
\text { coefficients }\end{array}$ & t & Sig. \\
\cline { 2 - 7 } & $\mathbf{B}$ & $\begin{array}{c}\text { Std. } \\
\text { error }\end{array}$ & Beta & & \\
\hline Constant & 4.564 & .036 & & 127.139 & .000 \\
\hdashline NPM & .024 & .011 & .129 & 2.225 & .027 \\
CSR & .062 & .043 & .083 & 1.426 & .155 \\
\hline
\end{tabular}

Based on Table 9, the effect of the residuals of independent variables is presented. Then the second residual test is carried out. Table 10 shows that test is an alternative test of various methods available.

Table 10. Results of the second residual test

Source: SPSS (2017)

\begin{tabular}{|c|c|c|c|c|c|}
\hline \multirow{2}{*}{ Model } & \multicolumn{2}{|c|}{$\begin{array}{c}\text { Unstandardized } \\
\text { coefficients }\end{array}$} & \multirow{2}{*}{$\frac{\begin{array}{c}\text { Standardized } \\
\text { coefficients }\end{array}}{\text { Beta }}$} & \multirow[t]{2}{*}{$t$} & \multirow{2}{*}{ Sig. } \\
\hline & B & Std. error & & & \\
\hline Constant & .132 & .026 & & 5.031 & .000 \\
\hline NP & .070 & .037 & .112 & 1.925 & .055 \\
\hline
\end{tabular}

The resulting moderation equation is:

$$
\begin{gathered}
Z_{1}=4.564+0.024 N P M+0.062 C S R+e, \\
|e|=0.132+0.0704 N P .
\end{gathered}
$$

The equation based on Table 10 produces positive and insignificant coefficient value of 0.070 because the significance value of firm value is 0.055 that is bigger than alpha 0.05 . So it is concluded that institutional ownership reinforced the relationship between net profit margin and corporate social responsibility and firm value.

\subsection{Discussion}

Corporate social responsibility (CSR) is a concept on how a company can contribute to society pro- 
gress. The term CSR is enough debatable. The business world also seems to be giddy with the word 'responsibility', whereas the role of the business world with its CSR practices is expected in the process of sustainable development in Indonesia. The condition of Indonesia still requires CSR as a legal obligation. In the past 10 years, some banking issuers have had minimal CSR implementation as a corporate social responsibility. Awareness of the existence of CSR is still low, the conditions that occur lack for sufficient moral awareness. Obedience of issuers to the need for social accountability is still very low. CSR is born from the people's insistence on the behavior of companies that ignore social responsibility, such as environmental destruction, exploitation of natural resources and exploitation of workers' rights. Most companies also tend to distance themselves from the surrounding community. If the situation and conditions that occur need to strengthen awareness of the company roles and responsibilities, then a non-legal responsibility will turn into liability or mandatory. This initiates the government to intervene with the aim of expanding the scope of CSR. The CSR scope covers not only corporate responsibility to shareholders, but also to stakeholders, employees, consumers, suppliers, communities, the creation of clean air, clean water, and other constituents where the company is located. CSR practices will have a positive impact on the company, and assess CSR as an investment, not a cost. Companies voluntarily and earnestly practice CSR and are confident that this social investment will result in the smooth operation of the business. They get a positive image because the community assesses the existence of the company to help the community.
The CSR practice is a long-term social investment. Implementing sustainable CSR practices will obtain operational permits from the community (Parida \& Wang, 2018; Stancu et al., 2018; Kanaiah \& Jayakumar, 2018; Lin et al., 2018; Bertrand \& Lapointe, 2018; Kumar et al., 2018; Kim, 2018; Del Brio et al., 2018; Ahigbe et al., 2018; Abukari \& Hamid, 2018). In order to have the force of law and stimulus, the CSR, that is all voluntary, needs to be upgraded to a more mandatory CSR. The measurable and systematic contribution of the business world in its participation improves the welfare of society and can boost the value of the company. If the value of the firm increases, then the stock price increases and the company's profit increases. Conversely, on the other hand, people also cannot casually make demands to the company, if expectations are beyond the limits of applicable rules. In conducting CSR activities, it is strongly recommended that the business community involve the local community, so that CSR activities produce positive impact not only for internal but also external companies. Community engagement activities directly in the region of the business world concerned are known as Community Development. Community development is a process designed to create the progress of the economic and social conditions of citizens through active participation, which in turn will foster initiative and self-reliance of the community itself. The concept of CSR is closely related to the concept of Community development. Community development is an important part of the implementation process of CSR activities.

\section{CONCLUSION}

Based on the research results, it is concluded that fundamental variables of a company, i.e. net profit margin and corporate social responsibility influenced the enterprise value, while variable net profit margin partially influenced firm value and variable corporate social responsibility didn't influence enterprise value. Institutional ownership variable could reinforce the relations of net profit margin and corporate social responsibility with the enterprise value. The enterprise value that is proxied by Tobin $\mathrm{Q}$ is an equation that describes the value of an enterprise from the point of market value. The balance of the market value is created if it is the same as the emergence of the replacement cost, namely the sacrificed attribute in the form of cash to be paid to obtain the same and similar assets at present or the amount of debt/liabilities that will be charged to obtain these assets. The test results show that investors' expectations only need fundamental information about trend of returns and stock prices. The company's CSR policy as material for consideration in its investment decisions is ignored. In addition, 
institutional ownership factors did not play a major role in the relationship. This is also summarized in the fact that banking issuers in Indonesia are minimal in disclosing their social responsibility reporting. It also plays a major role in investor decisions because there are not many issuers who disclose their social responsibilities in the notes to financial statements. The Indonesian capital market authority must appeal to banking issuers to increase their social disclosure so that the information plays a role in the value of the company.

\section{ACKNOWLEDGEMENT}

This paper is dedicated to the implementation of the Memorandum of Understanding (MoU) between the Universitas Sumatera Utara (USU), Indonesia, and Accounting Research Institute (ARI), Universiti Teknologi MARA, Malaysia.

\section{REFERENCES}

1. Abukari, A. J., \& Abdul-Hamid, I. K. (2018). Corporate social responsibility reporting in the telecommunications sector in Ghana. International Journal of Corporate Social Responsibility, 3(1), 2-12. https:// doi.org/10.1186/s40991-0170025-9

2. Adelopo, I., Obalola, M., \& Moure, R. C. (2017). Corporate social disclosures by banks: Between legal institution and cultural dimensions. In Sustainability and Social Responsibility: Regulation and Reporting (pp. 307-331). Singapore: Springer. https://doi. org/10.1007/978-981-10-45028_13

3. Akhigbe, A., Makar, S., Wang, L., \& Whyte, A. M. (2018). Interest rate derivatives use in banking: Market pricing implications of cash flow hedges. Journal of Banking \& Finance, 86, 113126. https://doi.org/10.1016/j. jbankfin.2017.09.009

4. Al-Abdin, A., Roy, T., \& Nicholson, J. D. (2017). Researching corporate social responsibility in the Middle East: the current state and future directions. Corporate Social Responsibility and Environmental Management, 25(1), 47-65. https://doi.org/10.1002/ csr. 1439

5. Ameer, R., \& Othman, R. (2018). Corporate Values and Corporate Social Responsibility
Communication Strategies in a Small Economy. In Eco-Efficiency in Industry and Science (pp. 67100). Cham: Springer. https://doi. org/10.1007/978-3-319-70899-7_4

6. Baldini, M. A., Bronzetti, G., \& Sicoli, G. (2018). The influence of corporate governance's decision on corporate social responsibility. International Journal of Business Performance Management, 19(1), 16-35. https://doi.org/10.1504/ijbpm.2018.10008953

7. Bedendo, M., \& Siming, L. (2018). The mitigating effect of bank financing on shareholder value and firm policies following rating downgrades. Journal of Corporate Finance, 48, 94-108. https://doi. org/10.1016/j.jcorpfin.2017.10.019

8. Bertrand, P., \& Lapointe, V. (2018). Risk-based strategies: the social responsibility of investment universes does matter. Annals of Operations Research, 262(2), 413-429. https://doi.org/10.1007/ s10479-015-2081-4

9. Bhardwaj, P., Chatterjee, P., Demir, K. D., \& Turut, O. (2018). When and how is corporate social responsibility profitable? Journal of Business Research, 84, 206-219.

10. Blasi, S., Caporin, M., \& Fontini, F. (2018). A Multidimensional Analysis of the Relationship Between Corporate Social Responsibility and Firms' Economic Performance. Ecological
Economics, 147, 218-229.

https://doi.org/10.1016/j.ecolecon.2018.01.014

11. Buchanan, B., Cao, C. X., \& Chen, C. (2018). Corporate social responsibility, firm value, and influential institutional ownership. Journal of Corporate Finance, 52, 73-95. https://doi. org/10.1016/j.jcorpfin.2018.07.004

12. Buranatrakul, T., \& Swierczek, F. W. (2017). Climate Change Strategic Actions in the International Banking Industry. Global Business Review, 19(1), 32-47. https://doi. org/10.1177/0972150917713371

13. Byun, S. K., \& Oh, J. M. (2018). Local corporate social responsibility, media coverage, and shareholder value. Journal of Banking \& Finance, 87, 68-86. https://doi.org/10.1016/j.jbankfin.2017.09.010

14. Chen, N., Liang, H. Y., \& Yu, M. T. (2018). Asset diversification and bank performance: Evidence from three Asian countries with a dual banking system. PacificBasin Finance Journal, 52, 4053. https://doi.org/10.1016/j. pacfin.2018.02.007

15. Chen, Y. C., Hung, M., \& Wang, Y. (2018). The effect of mandatory CSR disclosure on firm profitability and social externalities: Evidence from China. Journal of Accounting and Economics, 65(1), 169190. https://doi.org/10.1016/j. jacceco.2017.11.009 
16. Chou, Y. Y., \& Chan, M. L. (2018). The Impact of CEO Characteristics on Real Earnings Management: Evidence from the US Banking Industry. Journal of Applied Finance \& Banking, 8(2), 17-44.

17. Chung, K. H., \& Pruitt, S. W. (1994). A simple approximation of Tobin's q. Financial Management, 23(3), 70-74. https://doi. org/ $10.2307 / 3665623$

18. Civera, C., Casalegno, C., Mosca,F., \& Maple, P. (2018). Customers' judgments and misjudgments of corporate responsibility communication: A cross-country investigation of the effects on confidence and trust within the banking sector. Psychology \& Marketing, 35(2), 138-149. https:// doi.org/10.1002/mar.21075

19. Cordeiro, J. J., Galeazzo, A., Shaw, T. S., Veliyath, R., \& Nandakumar, M. K. (2018). Ownership influences on corporate social responsibility in the Indian context. Asia Pacific Journal of Management, 35(4), 1107-1136.

20. Corporate Finance Institute (2018). What is Net Profit Margin? Retrieved from https://corporatefinanceinstitute.com/resources/ knowledge/finance/net-profitmargin-formula/ (Acceses on December 22, 2018).

21. De Jong, M. D., Harkink, K. M., \& Barth, S. (2018) Making Green Stuff? Effects of Corporate Greenwashing on Consumers. Journal of Business and Technical Communication, 32(1), 77-112. https://doi. org/10.1177/1050651917729863

22. Del Brio, E. B., Perote, J., de Miguel, A., \& Gómez, G. (2018) Insider Trading and Corporate Governance in the Banking Sector. New Lessons on the Entrenchment Effect. In Corporate Governance in Banking and Investor Protection (pp. 219-233). Cham: Springer.

23. Eckardt, R., Skaggs, B. C., \& Lepak, D. P. (2018). An examination of the firm-level performance impact of cluster hiring in knowledgeintensive firms. Academy of
Management Journal, 61(3), 919-944. https://doi.org/10.5465/ amj.2016.0601

24. ElGammal, W., El-Kassar, A. N \& Canaan Messarra, L. (2018) Corporate ethics, governance and social responsibility in MENA countries. Management Decision, 56(1), 273-291.

25. Faller, C. M., \& Zu KnyphausenAufseb, D. (2018). Does equity ownership matter for corporate social responsibility? A literature review of theories and recent empirical findings. Journal of Business Ethics, 150(1), 15-40. https://doi.org/10.1007/s10551016-3122-x

26. Guiso, L., \& Rustichini, A. (2018). Understanding the size and profitability of firms: The role of a biological factor. Research in Economics, 72(1), 65-85

27. Hu,Y. Y., Zhu,Y., Tucker, J., \& Hu,Y. (2018). Ownership influence and CSR disclosure in China. Accounting Research Journal, 31(1), 8-21. https://doi. org/10.1108/arj-01-2017-0011

28. Idowu, S. O. (2018). Current Issues in Corporate Social Responsibility: An Introduction. In Current Issues in Corporate Social Responsibility (pp. 1-7). Cham: Springer.

29. Jaiyeoba, H. B., Adewale, A. A., \& Quadry, M. O. (2018). Are Malaysian Islamic banks' corporate social responsibilities effective? A stakeholders' view. International Journal of Bank Marketing, 36(1), 111-125. https://doi.org/10.1108/ ijbm-10-2016-0146

30. Jamali, D., \& Karam, C. (2018). Corporate social responsibility in developing countries as an emerging field of study. International Journal of Management Reviews, 20(1), 32-61.

31. Jie, C. T., \& Hasan, N. A. M. (2018). Predictors of Employees' Job Satisfaction Through Corporate Social Responsibility (CSR) Practices in Malaysian Banking Company. Advanced Science Letters, 24(5), 3072-3078. https:// doi.org/10.1166/asl.2018.11320

32. Jusoh, W. N. H. W., \& Ibrahim, U. (2018). The Significance of
Corporate Social Responsibility Disclosure to Islamic Banks in Malaysia: An Islamic View. Journal of Islamic Finance, 7(1), 1-8.

33. Kannaiah, D., \& Jayakumar, A. (2018). Impact of Corporate Social Responsibility (CSR) Practices on Consumer Behavior (with Reference to FMCGs in Tamil Nadu). International Journal of Business and Management, 13(3), 28. https://doi.org/10.5539/ijbm. v13n3p28

34. Kim, J. H. (2018). Asset specificity and firm value: Evidence from mergers. Journal of Corporate Finance, 48, 375-412.

35. Knudsen, J. S. (2018). Government Regulation of International Corporate Social Responsibility in the US and the UK: How Domestic Institutions Shape Mandatory and Supportive Initiatives. British Journal of Industrial Relations, 56(1), 164-188. https://doi.org/10.1111/bjir.12253

36. Kumar, R., Pande, N., \& Afreen, S. (2018). Developing a GRI-G4 based persuasive communication framework for sustainability reporting (SR): examining top 10 Indian banks. International Journal of Emerging Markets, 13(1), 136-161.

37. Lamb, N. H., \& Butler, F. C. (2018). The influence of family firms and institutional owners on corporate social responsibility performance. Business and Society, 57(7), 13741406. https://doi. org/10.1177/0007650316648443

38. Laoworapong, M., Supattarakul, S., \& Swierczek, F. W. (2018). Corporate Governance, Board Effectiveness, and Performance of Thai Listed Firms. AU Journal of Management, 13(1), 25-40.

39. Law No. 40 of 2007 on Limited Liability Company (2007). State Gazette of 2007 Number 106 (Supplement to the State Gazette Number 4756). Retrieved from https://cdn.indonesiainvestments.com/documents/ Company-Law-Indonesia-LawNo.-40-of-2007-on-LimitedLiability-Companies-IndonesiaInvestments.pdf 
40. Li, T., \& Zaiats, N. (2018). Corporate governance and firm value at dual class firms. Review of Financial Economics, 36(1), 47-71.

41. Lin, C., Chang, H., \& Zhu, H. (2018). The Relationship between Social Responsibility and Majority Shareholders' Stock Selling: Considering the Mediation of Investors Tendency. Journal of Business Theory and Practice, 6(1), 12. https://doi.org/10.22158/jbtp. v6n1p12

42. Loh, L., Thao, N. T .P., Lee, S. P., \& Thomas, T. (2018). Corporate Disclosure On Business Integrity in Asean. Retrieved from https:// www.scope.org.sg/phocadownload/BI\%20report\%20V6\%20 060818\%20-\%20final.pdf

43. Loosemore, M., \& Lim, B. T. H. (2018). Mapping corporate social responsibility strategies in the construction and engineering industry. Construction Management and Economics, 36(2), 67-82.

44. Maqbool, S., \& Zameer, M. N. (2018). Corporate social responsibility and financial performance: An empirical analysis of Indian banks. Future Business Journal, 4(1), 8493. https://doi.org/10.1016/j. fbj.2017.12.002

45. Motta, E. M., \& Uchida, K. (2018) Institutional investors, corporate social responsibility and stock price performance. Journal of the Japanese and International Economies, 47(1), 91-102.

46. Ngoc, N. (2018). The Effect of Corporate Social Responsibility Disclosure on Financial Performance: Evidence from Credit Institutions in Vietnam. Asian Social Science, 14(4), 109122. https://doi.org/10.5539/ass. v14n4p109

47. Parida, S., \& Wang, Z. (2018). Financial Crisis and Corporate Social Responsible Mutual Fund Flows. International Journal of Financial Studies, 6(1), 8. https:// doi.org/10.3390/ijfs6010008

48. Paynter, M., Halabi, A. K., \& Lawton, A. (2018). The NeoInstitutionalism Influences on
Corporate Social Responsibility Reporting Development in Australia: A Three Company Study. In The Goals of Sustainable Development (pp. 193-214). Singapore: Springer.

49. Rahman, I. M. A., \& Ismail, K. N. I. K. (2018). The moderating effect of culture on the relationship between women directors and CSR disclosure in Malaysia. Asian Journal of Accounting and Governance, 9, 133-148. Retrieved From http://ejournal.ukm.my/ ajac/article/view/25303

50. Rao, A. (2018). Empirical Analysis of Joint Impact of Enterprise Risk Management (ERM) and Corporate Governance (CG) on Firm Value. International Review of Advances in Business, Management and Law, 1(1), 34-50. https://doi.org/10.30585/irabml. v1i1.66

51. Salehzadeh, R., Pool, J. K., \& Najafabadi, A. H. J. (2018). Exploring the relationship between corporate social responsibility, brand image and brand equity in Iranian banking industry. Journal of Islamic Accounting and Business Research, 9(2), 106-118. https://doi. org/10.1108/jiabr-11-2014-0041

52. Salvioni, D. M., Franzoni, S., \& Gennari, F. (2018). Social Responsibility as a factor of Convergence in Corporate Governance.Sustainability and Social Responsibility: Regulation and Reporting (pp. 29-53). Singapore: Springer.

53. Saona, P., \& San Martín, P. (2018). Determinants of firm value in Latin America: an analysis of firm attributes and institutional factors. Review of Managerial Science, 12(1), 65-112. https://doi. org/10.1007/s11846-016-0213-0

54. Schipani, C. A., Dworkin, T. M., \& Liu, J. (2018). The role of employee voice in promoting corporate social responsibility in China. Globalisation of Corporate Social Responsibility and its Impact on Corporate Governance (pp. 5175). Cham: Springer

55. Sial, M. S., Chunmei, Z., Khan, T., \& Nguyen, V. K. (2018). Corporate social responsibility, firm performance and the moderating effect of earnings management in Chinese firms. Asia-Pacific Journal of Business Administration, 10(2/3), 184-199. https://doi.org/10.1108/ apjba-03-2018-0051

56. Spanos, L. (2018). Complementarity and interconnection between CSR and crowdfunding: A case study in Greece. In Corporate Responsibility and Digital Communities (pp. 2949). Cham: Palgrave Macmillan.

57. Stancu, A., Grigore, G., \& McQueen, D. (2017). Corporate Responsibility and Digital Communities: An Introduction. In Corporate Responsibility and Digital Communities (pp. 1-7). Cham: Palgrave Macmillan. https://doi.org/10.1007/978-3319-63480-7_1

58. Syahyunan, Muda, I., Siregar, H. S, Sadalia, I., \& Chandra, G. (2017). The Effect of Lerner Index and Income Diversification on the General Bank Stability in Indonesia. Banks and Bank Systems, 12(4), 56-64. http://dx.doi. org/10.21511/bbs.12(4).2017.05

59. Titus, V. K., \& Anderson, B. S. (2018). Firm Structure and Environment as Contingencies to the Corporate Venture Capital-Parent Firm Value Relationship. Entrepreneurship Theory and Practice, 42(3), 498522. https://doi.org/10.1111/ etap. 12264

60. Tran, B. (2018). Corporate social responsibility. In Encyclopedia of Information Science and Technology, Fourth Edition (pp. 671-681). IGI Global.

61. Vaidya, Dheeraj (2017). What Is Enterprise Value (Firm Value)? Retrieved from https://www. Wallstreetmojo.Com/EnterpriseValue/\#Calculation (Acceses on 22 December 2018) 